\title{
A revolução nas origens da esquerda católica brasileira e a Teologia da Libertação
}

\section{La revolución en los orígenes de la izquierda católica brasileña y la Teología de la Liberación}

\section{The Revolution in the Origins of the Brazilian Catholic Left and Liberation Theology}

\begin{abstract}
iD Wellington Teodoro da Silva
Pontifícia Universidade Católica de Minas Gerais, Belo Horizonte, Minas Gerais, Brasil wteodoro@pucminas.br
\end{abstract}

(iD) Paulo Agostinho N. Baptista

Pontifícia Universidade Católica de Minas Gerais, Belo Horizonte, Minas Gerais, Brasil pagostin@gmail.com

\begin{abstract}
Resumo: O tema da revolução ganha espaço importante no Brasil e na América Latina e Caribe no final da década de 1950 e no início da década de 1960. A vitoriosa revolução cubana (janeiro de 1959) alimenta o imaginário da juventude, incluindo a cristã. Os jovens católicos organizados na Ação Católica Especializada, especialmente na JUC, JOC e JEC, atuando em movimentos de educação, estudantis e sindicais, no campo e nas cidades, questionada, também se preocupa com a questão do empobrecimento, da desigualdade e da opressão. Assim, começava a avançar a ideia de uma esquerda católica e a necessidade de aliança com outros setores da sociedade civil que desejavam a transformação social e a revolução. E como o cristão poderia participar dessa realidade? Como ser cristão num mundo de miseráveis? Como ler e interpretar a dinâmica social e política que gerava exclusão? São questões que ocupam intelec-
\end{abstract}


tuais de várias tendências, especialmente cristãos. Começava um processo de elaboração de uma nova formulação da inteligência da fé, da teologia, a Teologia da Libertação. O presente artigo, a partir de pesquisa qualitativa bibliográfica, objetiva refletir sobre as ideias de revolução, a compreensão da revolução cristã, e como foi sendo construída, especialmente a partir da juventude cristã, a Teologia da Libertação.

Palavras-chave: Revolução. Esquerda católica. Teologia da libertação. Juventude

Resumen: El tema de la revolución ganó un espacio importante en Brasil y América Latina y el Caribe a fines de los años 50 y principios de los 60. La victoriosa revolución cubana (enero de 1959) alimenta el imaginario de la juventud, incluido la cristiana. Los jóvenes católicos organizados en Acción Católica Especializada, especialmente en la JUC, JOC y JEC, que han trabajado en educación, movimientos estudiantiles y sindicales, en el campo y en las ciudades, los han sentidose presionados y también están preocupados por el tema del empobrecimiento, la desigualdad y la opresión. Así comenzó a avanzar la idea de una izquierda católica y la necesidad de alianza con otros sectores de la sociedad civil que deseaban la transformación social y la revolución. ¿Y cómo podría el cristiano participar en esta realidad? ¿Cómo ser cristiano en un mundo miserable? ¿Cómo leer e interpretar la dinámica social y política que generó la exclusión? Estas son preguntas que ocupan intelectuales de diversas tendencias, especialmente cristianos. Comenzó un proceso de elaboración de una nueva formulación de la inteligencia de la fe, de la teología, la Teología de la Liberación. Este artículo, basado en la investigación bibliográfica cualitativa, tiene como objetivo reflexionar sobre las ideas de la revolución, la comprensión de la revolución cristiana y cómo se estaba construyendo, especialmente desde la juventud cristiana, la Teología de la Liberación.

Palabras clave: Revolución. Izquierda católica. Teología de la liberación. Juventude. 
Abstract: The theme of revolution gained important space in Brazil, Latin America and the Caribbean in the late 1950s and early 1960s. The successful Cuban revolution (January 1959) feeds the imaginary of youth, including the Christians. Young Catholics organized in the Specialized Catholic Action, especially in the JUC, JOC and JEC, working in education, student and trade union movements, in the countryside and in the cities, are also concerned with the issue of impoverishment, inequality and oppression. And so the idea of a Catholic Left and the need for alliance with other sectors of civil society that wanted social transformation and revolution began to advance. And how could the Christians participate in this reality? How to be a Christian in a miserable world? How to read and interpret the social and political dynamics that generated exclusion? These are questions that occupy intellectuals of various tendencies, especially Christians. A process of elaborating a new formulation of the intelligence of faith, of theology, the Theology of Liberation then began. This article, based on qualitative bibliographic research, aims at reflecting on the ideas of revolution, the understanding of the Christian revolution, and how it was being built, especially from the Christian youth, the Theology of Liberation.

Keywords: Revolution. Catholic Left. Theology of Liberation. Youth

Data de recebimento: 31/07/2019

Data de aceite: 08/10/2019

A todas e todos que foram martirizados na luta pela libertação “O jovem não é o amanhã, ele é o agora". Herbert de Souza (Betinho) 


\section{Introdução}

A revolução e a modernidade se coabitam e se coproduzem. A intensidade transformadora da revolução necessitou de um momento próprio da história para acontecer. A modernidade foi esse momento que, por seu lado, apenas poderia surgir na história pela via revolucionária. Após essa mútua produção, tudo o que é moderno está para ser revolucionado. Ou, mais ainda, está em revolução, se desfazendo no ar (BERMANN, 1986).

Setores do catolicismo, especialmente na década de 1960, ocuparam-se do anticapitalismo uma vez que os setores conservadores se ocupavam apenas do anticomunismo. Assim, davam maior ênfase ao caráter anticapitalista da doutrina social católica expressa dos documentos papais. Compreendiam que o capitalismo não produzia o bem comum por estruturar-se, de forma ateia, na busca do lucro e na livre competição. O ser humano, criado à imagem de Deus, é substituído pelo capital no centro estruturador de seu funcionamento. Seu liberalismo econômico deveria ser combatido por ser contrário à compreensão comunitária do cristianismo, que recusa o indivíduo liberal a favor da pessoa humana (RUBIO, 2001, p. 303-317). Esse sistema econômico desrespeita o plano do Criador por impedir o acesso de todas as pessoas aos bens necessários à vida de todos.

O caráter sistêmico do capitalismo impunha a necessidade de mudanças além da superfície por ser materialista e totalmente condenável. Segundo Paulo de Tarso, simples reformas não conseguiriam fazer a mudança no eixo do sistema do lucro que o magistério da Igreja Católica exigia, orientando-o para o valor inestimável da pessoa; a mudança nesse sistema aconteceria apenas pela via revolucionária, pois “o cristianismo autêntico é revolução há 20 séculos" (TARSO, 1963, p. 43). O autor alerta para o erro dos cristãos que defendiam o capitalismo como forma de fazer oposição ao comunismo. Eles recusavam um ateísmo para defender outro, ambos condenáveis. 
A revolução nas origens da esquerda católica brasileira e a Teologia da Libertação Wellington Teodoro da Silva • Paulo Agostinho N. Baptista

O capitalismo dissimula seu materialismo confundindo-se com o cristianismo. O comunismo, por sua vez, impõe o seu materialismo. Segundo Tarso (1963), isso confundia os cristãos, que chegavam a pensar que o comunismo era o único sistema político e econômico que se orienta a partir de fundamentos ateus. Ambas estruturas negam os valores cristãos e devem, portanto, ser recusados pelos cristãos que não poderiam se render nem à lógica do livre mercado e da livre empresa do capitalismo e tampouco ao totalitarismo do Estado comunista.

Nesse contexto, o setor conhecido como esquerda católica apareceu entre fins da década de 1950 e primeira metade da década de 1960. Ele coincide com o momento em que, segundo Celso Furtado (1962), a economia do país havia alcançado um grau de diferenciação que permitiria transferir para os brasileiros os principais centros decisórios de sua vida econômica. Cumpria-Ihes, naquele momento, construir uma filosofia que orientasse a ação. $\mathrm{E}$ hoje é importante retomar essa história e conhecer seu processo.

Desta forma, o objetivo deste artigo é refletir sobre a revolução que se fez presente na consciência e na práxis da esquerda católica brasileira, ${ }^{1}$ produzindo inclusive uma nova forma de se fazer teologia. Além de contextualizar o surgimento desta questão, o estudo busca situar o que seria a "revolução na perspectiva cristã". Tal visão acabou se transformando em ação, em práxis, especialmente da juventude. A última parte do artigo discutirá como essa revolução cristã se transformou em teologia da, na e pela práxis libertadora. Essa juventude, articulada ao redor dos grupos de Ação Católica Especializada - JAC, JEC, JIC, JOC e JUC - especialmente como JUC, JOC e JEC, fez emergir, não enquanto teoria, mas como ação transformadora, uma nova maneira de fazer teologia: a Teologia da Libertação.

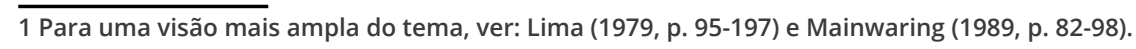




\section{Contextualizando a ideia de esquerda católica brasileira}

O termo "esquerda católica" foi formulado pelos conservadores para designar os grupos que, por sua excessiva politização, não poderiam ser compreendidos como católicos ao lado dos demais. Pedro Ribeiro de Oliveira afirma que, antes do trabalho de Cândido Mendes de Almeida (ALMEIDA, 1966), essa "expressão era usada pelo pensamento conservador para desqualificar aqueles grupos e intelectuais, porque, no contexto de combate religioso ao 'comunismo ateu', quem fosse de 'esquerda' não poderia ser autenticamente católico" (OLIVEIRA, 2007, p. 33).

As formulações desse catolicismo estão situadas em um mundo em efervescência: a revolução cubana aparece como um furacão fascinante (SARTRE, 1960); no Brasil, a sociedade civil se organizava no meio urbano e rural de maneira ainda não vivida em sua história política; os Estados Unidos passavam pelas reivindicações dos direitos civis etc.

Por seu lado, alguns católicos descobriram que o marxismo fazia constatações plausíveis da realidade e que o diálogo com o comunismo era possível e desejável. Vale lembrar, ainda, o padre Camilo Torres, que foi, segundo Luiz Carlos Bresser-Pereira (2006), o maior herói revolucionário da América Latina depois de Che Guevara. A esse tempo novo, esperançoso e turbulento, o papa João XXIII responde com o anúncio do Concílio Vaticano II e com as encíclicas Mater et Magistra (1961) e Pacem in Terris (1963).

A esquerda católica no Brasil principia como um movimento de ideias já na década de 1940, através das conferências do Padre Lebret e de frei Benevenuto de Santa Cruz. Como movimento organizado num corpo coerente de assertivas, ela surge a partir da segunda metade da década de 1950. Entretanto, no início da década de 1960, consegue apresentar-se com contornos mais observáveis para o estudioso, especialmente na Ação Católica Especializada e na Ação Popular. O seu fim, como movimento, acontece por volta de três anos após o Golpe Militar de 1964 (OLIVEIRA, 1992, p. 44). 
A revolução nas origens da esquerda católica brasileira e a Teologia da Libertação Wellington Teodoro da Silva • Paulo Agostinho N. Baptista

A revolução foi uma das ideias-força do período. Diversos atores da política acreditavam que a sociedade estava em pleno processo revolucionário. A revolução foi um núcleo duro, produtor de ideias e sentidos, orientador das ações e formulador da identidade da esquerda católica. O sentimento de que a realidade estava em trânsito vigoroso foi notado por Celso Furtado em suas aulas e palestras:

Em meus contatos com a juventude universitária, de todo o Brasil, tenho observado que crescentes ansiedades dominam os espíritos. Generalizou-se a consciência de que o país caminha para transformações de grande alcance; e de que, sob nossos pés, como uma torrente profunda, trabalham forças insondáveis. E todos, ou quase todos, os jovens desejam compreender o que está ocorrendo e pretendem participar conscientemente dessas transformações [...] exigindo de todos nós definição clara de posições: identificação corajosa de objetivos e métodos na luta pela conquista do futuro. (FURTADO, 1962, p. 13).

A lida com o tema revolução foi um dos modos pelos quais a modernidade chegou no interior do catolicismo brasileiro. Esses católicos compreendiam a revolução como morte e ressurgimento de estruturas e mentalidades novas na história. Defendiam que o cristianismo, a religião de historiadores para Bloch (2001), é o pedagogo desse evento-força. Ele está inscrito na matriz que lida com a ideia e a fé na ressurreição que, por sua vez, se traduz na superação da morte pela vida eterna: realidade nova no Absoluto.

A ressurreição e a revolução superam uma dada realidade e inauguram outra que ultrapassa em tudo a anterior. O nascimento e a ressurreição do Filho de Deus deram à história o estatuto de coisa elevada em seus sentidos e significados, ganhando densidade e gramatura capazes de produzir e conduzir o fenômeno revolução; pela possibilidade de comportar Deus ela consegue comportar a revolução. Para esses católicos, o ato revolucionário é mais propriamente cristão do que marxista e, portanto, cumpria-Ihes devolvê-lo ao seu lugar original. 
A revolução nas origens da esquerda católica brasileira e a Teologia da Libertação Wellington Teodoro da Silva • Paulo Agostinho N. Baptista

A revolução, conforme assevera Hannah Arendt (2003), é um evento moderno que não encontra laços de continuidade em sua natureza com o passado clássico; à exceção do que a autora denomina de materialismo de Aristóteles, que compreendeu o papel das questões econômicas em animar as atividades de mudanças e rupturas políticas. Os antigos conheciam o trânsito político e a sua violência. No entanto, eles não concebiam a mudança como rupturas e novos começos naquilo que a modernidade viria a compreender como história. A revolução apresenta uma novidade: o problema e a tarefa de um novo recomeço; o passado como entuIho para a ser superado e a abertura ao futuro generoso.

\section{A revolução na perspectiva cristã}

Como resultado de palestras, conferências e cursos sobre a encíclica Mater et Magistra (1961) de João XXIII, o dominicano Carlos Josaphat publicou o livro Evangelho e revolução social no ano de 1962. Trata-se de uma obra seminal e fundamental para compreender o catolicismo brasileiro diante das questões sociais da segunda metade do século XX. Na obra, o autor defende que os cristãos deveriam elaborar as questões políticas fora das oposições capitalismo versus comunismo do período, partindo da compreensão integral do humano. Deveriam produzir sínteses "acima dos mitos da direita e da esquerda, superando a exploração capitalista e a opressão comunista; essa concepção integral do homem constitui o elã animador da atual renovação cristã" (JOSAPHAT, 2002. p. 9 e 10). As questões de cada época deveriam ser analisadas na sensibilidade dos problemas humanos, no sentido dos mistérios divinos. O cristianismo poderia ser uma força conservadora ou revolucionária; deveria conservar a realidade histórica boa, que promova o bem comum. Por outro lado, deve levar à revolução uma realidade que impeça a promoção do humano.

O tema da revolução impôs ao frade tratar do marxismo. Não Ihe espantava o fascínio que ele exercia sobre as mentalidades por 
A revolução nas origens da esquerda católica brasileira e a Teologia da Libertação Wellington Teodoro da Silva • Paulo Agostinho N. Baptista

conter o imperativo do movimento da história, "a magia de uma escatologia mais acessível e mais humana do que a mensagem da esperança cristã" (JOSAPHAT, 2002. p. 26). O fixismo, a imobilidade e a debilidade dos cristãos em suas compreensões do mundo eram o real motivo de seu espanto.

Josaphat (2002) afirma que o marxismo possuía uma escatologia e uma visão da história cujas matrizes não foram por ele produzidas. Seus fundamentos geradores eram princípios cristãos secularizados. O autor vincula essa asserção à encíclica Divini Redemptoris, do papa Pio XI, de 19 de março de 1937, que identificava no comunismo essa imitação laicizada dos grandes dogmas cristãos.

Josaphat (2002) compreende o marxismo como uma radicalização humanista. A fé total na capacidade revolucionária do ser humano como o único responsável pela sua redenção na história. O fascínio que ele exerce é compreensível diante do imobilismo e pessimismo dos cristãos nos últimos séculos. Segundo o autor, ainda que o marxismo estivesse equivocado no seu materialismo, não deveria ser condenado como um mal em si, uma doença ou um inimigo da espécie humana, como defendiam os setores anticomunistas. O cristão deveria propor o diálogo, valorizando a história, o humano e o transcendente. Desse modo, o cristianismo resgataria o seu estatuto de fonte de compreensão e consciência da história.

Celso Furtado (1962) acompanha as ideias de Josaphat (2002) reputando ao marxismo a condição de resposta aos anseios profundos do homem moderno. Ele estende suas raízes ao humanismo renascentista que colocou o ser humano como centro e produtor de seu próprio destino. Ao tratar da questão dos jovens, Furtado (1962) elabora uma resposta que também é útil para pensar o catolicismo: para eles a análise dos processos sociais e econômicos é necessária orientadora da ideia de que a realidade é resultado da atividade humana e produz um estado de intranquilidade que apenas pode ser superado pela ação. Por sua vez, "o marxismo, em qualquer de suas variantes, permite traduzir o diagnóstico de dada realidade social em normas de ação" (FURTADO, 1962, p. 18). 
A revolução nas origens da esquerda católica brasileira e a Teologia da Libertação Wellington Teodoro da Silva • Paulo Agostinho N. Baptista

Josaphat e demais intelectuais, nas origens da esquerda católica, apresentam o cristianismo como orientador da mudança social e econômica, embora a crítica da militância cristã considerasse como otimismo ingênuo a compreensão profana de história elaborada pelo marxismo por causa de sua certeza profética e suas simplificações unilaterais. O diálogo deveria acontecer sem considerar o comunismo como um materialismo grosseiro.

O sucesso da revolução marxista, segundo Josaphat (2002), devia-se à aliança entre realismo e idealismo: apresenta a efetividade da ação no presente com forte esperança no futuro. $O$ revolucionário marxista doava-se desinteressadamente com a segurança quase palpável na vitória de uma causa superior que elevaria a condição humana até a sua emancipação. Desse modo, ele fascinava os sonhadores e idealistas e apresentava um humanismo grandemente satisfatório na exaltação do humano.

Josaphat (2002) questiona se, diante do otimismo marxista, os cristãos estariam reagindo numa dialética defensiva, de pessimismo histórico, afirmando e refugiando-se exclusivamente nos aspectos transcendentes da escatologia evangélica. A postura cristã deveria negar essa evasão da história e afirmar a fidelidade ao Evangelho, que supõe fidelidade ao tempo presente.

Como tomista, o autor assegura que a posição do cristão deveria fundar-se na plena "Caridade". Atenta para o fato de que a caridade fora reduzida à esmola ao indigente, que é um de seus aspectos mais que secundários. O exemplo de Cristo demonstrava que, efetivamente, a caridade era doação que poderia levar ao sacrifício da própria vida na ação de promoção da felicidade para todos. Essa caridade visa proporcionar ao outro o que lhe é necessário no plano espiritual e no plano material, valorizando e elevando a "sua dignidade de imagem e de filho de Deus" (JOSAPHAT, 2002, p. 17).

Caridade impõe a busca das causas profundas das condições sociais, econômicas e políticas que atentam contra a dignidade da imagem e dos filhos de Deus. A engenhosidade humana desen- 
A revolução nas origens da esquerda católica brasileira e a Teologia da Libertação Wellington Teodoro da Silva • Paulo Agostinho N. Baptista

volveu-se suficientemente de modo a permitir compreender que o empobrecimento era uma realidade decorrente de estruturas historicamente construídas. Portanto, a caridade, fonte de todas as virtudes, impunha ao cristão a ação por sobre essas estruturas produtoras de empobrecidos. A caridade anima a justiça social e não existe sem ela.

O Evangelho, como assevera Josaphat (2002), conduz o fiel à espiritualidade empenhada na construção de uma ordem social de solidariedade e justiça, espiritualidade que os cristãos deixaram de viver por muitos séculos. Entretanto, a geração que surgia estava despertando para esse imperativo vital do cristianismo no mesmo momento em que as ideologias, sobretudo o marxismo, exerciam fascínios.

Josaphat (2002) identifica, naquele momento, pelo menos duas ideologias: a conservadora e a revolucionária. Como religião profética, o cristianismo não deveria, contudo, elaborar-se numa ideologia que viesse a justificar uma posição conservadora ou revolucionária. O Reino anunciado pelo cristianismo atinge o ser humano por completo, tanto o seu coração quanto a sua dimensão histórica e social. Ele não é eticamente indiferente com a história e é marcado pela sede de justiça. Os profetas "são oráculos contra aqueles que se munem da religião a fim de guardar a boa consciência e prolongar sua boa vida. Com grande sofrimento pessoal, os profetas combatem essa religião que se torna baluarte da injustiça e da exploração" (JOSAPHAT, 2002, p. 33).

A seguir, Josaphat (2002) mostra que Cristo veio para realizar os anúncios dos profetas com perfeição. A encarnação do Verbo inaugura o Reino por meio do dom da graça e da difusão do Espírito Santo nos corações. A justiça e a paz anunciadas deveriam acontecer na história por meio da ação dos cristãos. O individualismo se constitui num escândalo para o cristão porque revelava que o Reino de Deus não chegou onde deveria chegar: no plano social. É escandaloso, para o autor, que o cristão viva de modo indiferente com a ausência de equidade, por um lado, e a sede de justiça, por outro. 
A revolução nas origens da esquerda católica brasileira e a Teologia da Libertação Wellington Teodoro da Silva • Paulo Agostinho N. Baptista

A revolução deve instaurar a verdadeira paz. A atividade histórica dos cristãos na promoção do bem comum é força dinâmica da história e ato salvífico. Partindo de Santo Tomás de Aquino, Josaphat (2002) retoma a ideia da verdadeira paz que é mais que a simples concordância e que, dialeticamente, o universo é providencialmente atravessado por um grande anseio de paz. A paz cristã dirige-se à verdadeira paz no céu, construindo a paz na terra. A paz na terra será sempre imperfeita por estar associada às contingências humanas. O autor lembra que para Tomás de Aquino a paz é a perfeita unidade interior do ser humano e sua união com Deus e com os semelhantes. Ela é fruto da caridade e preparada pela justiça. A justiça permite a realização da paz reconhecendo os direitos de cada pessoa e da comunidade humana. Portanto, em situações injustas, o combate pela justiça é a atitude inicial de quem procura a paz.

A defesa de Santo Tomás de Aquino da necessidade do cristão de se opor à má concórdia, à falsa paz, é compreendida como audaciosa por Josaphat (2002). Para Tomás de Aquino, o cristão deve desmanchar a tranquilidade dos acordos injustos. Sobre esse ponto, Josaphat (2002) traduz o seguinte fragmento:

\footnotetext{
Fomentar a discórdia pela qual se rompe a boa concórdia, fruto da caridade, é pecado grave, como ensina a Sagrada Escritura [cita-se Pr. 6, 16-19] [...] mas causar a discórdia para quebrar uma concórdia má, isto é: um acordo fundado na vontade má é atitude louvável. Disso nos dá exemplo o apóstolo Paulo (cf. At 15-39) e o próprio Senhor diz de si mesmo: 'Não vim trazer a paz, mas a espada' (cf. Mt. 10-34). ${ }^{2}$
}

Josaphat (2002) defende, assim, que a moderna reivindicação social deveria inserir-se no prolongamento da teologia clássica. Reivindicar deve ser compreendido como ato de caridade e de justiça. A revolução encontra lastro na tradição tomista por ser a quebra da concórdia má.

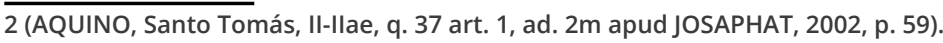


A revolução nas origens da esquerda católica brasileira e a Teologia da Libertação Wellington Teodoro da Silva • Paulo Agostinho N. Baptista

À medida que o mundo crê na mudança e que ela se torna um imperativo do momento histórico, o cristianismo se vê diante de uma renovação evangélica que consegue responder e animar com fecundidade o social. O amor cristão deve colocar a inteligência a serviço do "aprimoramento de todas as estruturas que condicionam a vida do homem contemporâneo" (JOSAPHAT, 2002, p. 67). Os regimes existentes deveriam receber inconformismo e repúdio dos cristãos, que deveriam promover sua superação revolucionária:

A caridade cristã, que outrora suscitou hospitais, leprosários, orfanatos, mil modalidades de obras de misericórdia, pode hoje ter a lucidez e a coragem de descer até à principal raiz dos males e misérias: as injustiças generalizadas, as estruturas sociais viciadas ou inadequadas, as instituições e as atividades políticas, consciente ou inconscientemente colocadas a serviço dos grupos, de regiões, de classes, em detrimento de dedicação total, racional e planificada ao bem comum dos países e da humanidade. (JOSAPHAT, 2002. p. 67).

Assim como Caio Prado Júnior (2004), Carlos Josaphat compreende que a revolução é definida pelo conteúdo da mudança e não pelos modos como ela acontece. O recurso às armas não é necessário para que o mundo se revolucione. A ideia da violência e do conteúdo predominantemente político da revolução é comum no século XIX, que se estende ao longo do século XX. Josaphat (2002) informa que, no momento que escreve, a revolução estava sendo definida de modo distinto do levante militar ou da guerra civil. Seu sentido fundamental era a mudança radical das estruturas econômico-político-sociais. A revolução era compreendida como processo histórico que produz transformações que não recuam - não se desconstroem - para a forma anterior, superada. É um processo de transformações sucessivas no plano da política, da economia, da sociedade: 
A revolução nas origens da esquerda católica brasileira e a Teologia da Libertação Wellington Teodoro da Silva • Paulo Agostinho N. Baptista

"Revolução" em seu sentido real e profundo, significa o processo histórico assinalado por reformas e modificações econômicas, sociais e políticas sucessivas, que, concentradas em período histórico relativamente curto, vão dar em transformações estruturais da sociedade, e em especial das relações econômicas e do equilíbrio recíproco das diferentes classes e categorias sociais. O ritmo da História não é uniforme. Nele se alternam períodos ou fases de relativa estabilidade e aparente imobilidade, com momentos de ativação da vida político-social e bruscas mudanças em que se alteram profunda e aceleradamente as relações sociais. Ou mais precisamente, em que as instituições políticas, econômicas e sociais se remodelam a fim de melhor se ajustarem e melhor atenderem à necessidade generalizada que antes não encontrava devida satisfação. (PRADO JUNIOR, 2004. p. 11-12).

Naquele momento, a revolução se diferenciava da evolução, que se baseava em um processo lento das instituições e do sistema por elas constituído e de sua ordem jurídico-legal. A revolução viria a ser:

a mudança brusca, postulada sempre que se verifique um hiato entre o dinamismo social e as estruturas. A revolução será uma necessidade sempre que se verifique um atraso, um retardamento no processo evolutivo, ou, quando um aceleramento no progresso, sobretudo no setor econômico, estabeleça um desequilíbrio, um desajuste entre as necessidades e as aspirações do conjunto do povo e a ordem jurídico-política vigente. (JOSAPHAT, 2002. p. 71-72).

Desse modo, Josaphat (2002) assegura não existir identidade entre revolução social e guerra civil. O recurso às armas pode ser necessário em caso de resistência da ordem injusta estabelecida. Ela seria apenas o meio preparatório para permitir a realização das mudanças necessárias nas estruturas ou instituições que, efe- 
tivamente, constituem a revolução. O cristão não apresenta a violência como expediente; seus critérios são a verdade, a bondade e o amor. Ele não acredita na violência para a mudança profunda do ser humano e nem para elaborar instituições duradouras. No entanto, o autor defende que, se meios de persuasão não podem ser acessíveis e utilizados pelos cristãos, e a tirania econômica continuar evidente, usando de meios publicitários para imperar, manipulando assim a imaginação, então nesse caso questiona se o cristão teria o direito de se defender empregando meios eficazes para desmantelar a máquina opressora. Para ele, a resposta seria afirmativa. No exercício do seu direito de defesa, o cristão deveria escolher suas armas numa escala de valores. Não pode perder de vista o bem maior que se orienta para o Supremo Bem e deve se preocupar em causar o menor mal possível. Antes de recorrer à violência, o cristão deverá tentar todos os meios de pressão moral e de resistência passiva, sempre que eles tiverem probabilidade de eficácia. Apenas no limite extremo ele poderá aplicar a força física para a mudança das estruturas iníquas.

Num primeiro momento, a luta deveria recorrer ao plano especificamente doutrinal e de persuasão, por todos os meios ao seu alcance. Em caso de fracasso nessa etapa, seria lançada a pressão moral e social para conduzir as estruturas iníquas ao ridículo e ao menosprezo da opinião. No terceiro momento, dever-se-ia agir por meio de resistência passiva, como as greves. Em último caso, seria aplicado à conjuntura aquilo que, segundo Josaphat (2002), ensina a teologia clássica tomista quando trata do direito e do dever de rebelião contra a tirania. A rebelião armada pode ser o recurso extremo para remover uma estrutura injusta a favor de uma renovação justa, radical e duradoura. Esse momento seria a fase militar da revolução, que deveria ser ativada quando se tivesse a certeza moral da vitória.

O autor lembra que o recurso à via militar é opção apenas se os cristãos ficarem inertes diante das situações de injustiças que vão se estruturando e mantendo-se no tempo. A omissão dos cristãos levaria a outros setores mais organizados a proporem-se como condutores do processo revolucionário. Espera-se, nesse 
A revolução nas origens da esquerda católica brasileira e a Teologia da Libertação Wellington Teodoro da Silva • Paulo Agostinho N. Baptista

caso, que possam conduzir de maneira adequada, atendendo às expectativas dos setores sadios da sociedade. Desse modo, ele situa no ambiente teológico brasileiro o tema da guerra justa.

Luiz Alberto Gómez de Souza também compreende a revolução como uma ideia-força que se apresenta como um imperativo irresistível e incontornável na consciência da esquerda católica, conferindo sentido e significado para o próprio cristianismo como princípio revolucionário da história. Esse princípio recusa a separação entre o mundo e o Reino que faz o cristão se distanciar das questões sociais, econômicas e políticas. Cumpria-lhe o vigor intelectual e de sentido profundo de estar no real histórico, situando-se no real mais real que é Jesus Cristo encarnado. Gómez de Souza (1962) distingue as reflexões da esquerda católica das concepções ateias ou falsamente ateias. Trata-se de abraçar o imanente e o transcendente na adesão vital a Jesus Cristo, Filho de Deus Vivo.

Esses cristãos negam-se a ver o cristianismo como uma simples doutrina a que se adere com a inteligência fria e distante. Essa fé não pode se reduzir a uma filosofia ou qualquer ordem de ideia por ser a síntese da relação, da unidade de uma Pessoa, Real, Histórica e Divina. Em Jesus Cristo, o Reino de Deus principia na história que é parte da criação divina. Contudo, o cristão deveria evitar o otimismo ingênuo e se lembrar do otimismo trágico tratado por Emmanuel Mounier. A fé nega que a história seja um absurdo e revela seu sentido no absoluto. A descoberta desse sentido impõe ao cristão a tarefa de participar dos processos históricos com vistas à consumação final dos tempos.

Souza (1962) prossegue afirmando que o real para o cristão é o Brasil subdesenvolvido e explorado, e sua missão nesse lugar é lutar contra tudo que impede a dignidade e as possibilidades de crescimento do humano. O compromisso deve ser com todos que estão fora do poder, os pobres e dominados. Essa é a perspectiva evangélica porque Jesus preferia os humildes. A consequência lógica dessa atitude seria a opção pela revolução brasileira e a transformação radical das estruturas que mantinham o polo dominan- 
A revolução nas origens da esquerda católica brasileira e a Teologia da Libertação Wellington Teodoro da Silva • Paulo Agostinho N. Baptista

te da sociedade, sempre em situações de mando e privilégios, às custas da miséria e exploração da nação.

Em sua breve e incendiária passagem pelo Brasil na primeira metade da década de 1960, o Frei Tomas Cardonnel, outro dominicano, também ajuda a organizar o pensamento dos setores de esquerda do catolicismo. Do mesmo modo que Carlos Josaphat e Paulo de Tarso, o Frei ocupa-se do tema capitalismo e comunismo de maneira obrigatória para compreender a revolução cristã. Trata atentamente do anticomunismo católico porque acredita que ele erra em suas asserções e acaba por defender o capitalismo, que também é um regime ateu e idólatra.

Em seu texto "Deus não é mentiroso como certa paz social", Cardonnel (1962, p. 19-23) trata da histeria anticomunista que afirma que o mal estava geograficamente situado no Leste. De acordo com o Frei, o mal também estava no ocidente capitalista. Se o comunismo sufocava o humano no coletivismo, o capitalismo liberal o reduz à situação atomizante do indivíduo. O cristianismo, por seu lado, recusava a ambos por compreender que os seres humanos são todos irmãos. Em termos políticos modernos isso pode ser um complicador.

Segundo Hannah Arendt (2003), a ideia de Santo Agostinho de organizar a sociedade a partir da noção de que ela é composta por irmãos fragiliza a sua politicidade. Como a autora explica, cidadania é um conceito político por excelência; o cidadão é político e o irmão é vazio de politicidade. A família não possui a virtude de organizar a vida em comum no espaço público porque ele não é, por definição, um espaço familiar. A cidadania e a irmandade, a família e o espaço público não se associam em suas naturezas, que são distintas e irredutíveis. No entanto, a reflexão de Cardonnel (1962) não exclui a política como fundamento da organização social. A abertura ao transcendente não é fuga ou recusa da história pelo cristão, que crê num Deus histórico que fez a opção por vivê-la, encarnando-se na condição humana. Arendt (2003) deveria ter considerado o fato da historicidade e, portanto, a politicidade de Jesus de Nazaré. 
A política em seus próprios termos é abraçada sem redução ou contradição pelo cristão. Cidadão e irmão não são realidades situadas como centros geográficos onde apenas um pode existir. Para o fiel, a política não é o fim último porque há uma realidade que a transcende. $\mathrm{O}$ cristão anuncia o fim da política ao anunciar o final dos tempos. Contudo, até essa consumação final, a política segue em seu sentido forte na história.

Viver a política, mesmo quando ela atinge a sua máxima dramaticidade na revolução, assume dimensão salvífica. Essa política não pode ser a do individualismo liberal e nem a do coletivismo comunista. A mudança necessária aconteceria na superação do capitalismo e dos socialismos existentes. Cardonnel (1962) preocupava-se, sobretudo, com a mudança da natureza do poder. Ela não deveria ser de dominação, mas de participação justa e igualitária.

O idealismo era o grande perigo para o cristão, que não deve contemplar uma vaga ideia de Deus, esquecendo-se do acontecimento histórico do Filho de Deus que se tornou homem. Cardonnel (1962) propõe um giro revolucionário de um ser humano historicamente situado e finito que se abre ao Absoluto quando afirma que Deus ensina a viver como homens para despertar nos seres humanos o gosto de uma vida de Deuses: Deus se humaniza para que o humano se divinize. O ser humano é uma realidade criada que é chamada a criar, dentro de uma unidade fundamental na humanidade e entre ela e Deus.

Naquele momento em que os católicos de esquerda elaboravam uma nova compreensão sobre o cristão no mundo, sentia-se que a realidade estava mudando revolucionariamente, que se vivia um momento de inflexão histórica. A revolução era uma espécie de ser que inebriava as mentalidades com seu movimento que tudo transforma. A alienação e a negação da ação eram grandes pecados.

Participar nesse processo de trânsito e rupturas era ato da afirmação do humano em sua condição de construtor de si e de mundos. O movimento é o fundamento do real. Por seu lado, o cristão deveria assumir a vanguarda por causa do imperativo da 
A revolução nas origens da esquerda católica brasileira e a Teologia da Libertação Wellington Teodoro da Silva • Paulo Agostinho N. Baptista

encarnação de Jesus Cristo. Embora a política seja tratada com vistas ao momento escatológico, o Estado, monopolizador moderno do poder de julgar e punir, é produto da elaboração humana cuja origem deve ser buscada apenas na natureza humana. Essa natureza, por sua vez, não é compreendida segundo o materialismo do século XIX:

A filosofia católica da política afirma que a origem do Estado se acha na natureza humana [...]. O Estado se origina na natureza corporal e espiritual do homem. A natureza, ou essência, é também fim da atividade do homem e de seu esforço. O Estado político é, pois, necessário para a realização do fim do homem; o Estado é disposição intencional da natureza humana (ROMMEN, 1967, p. 214).

Com posição parecida desses autores apresentados, poucos anos mais tarde, depois do golpe civil-militar de 1964, o professor de ética da UFJF, padre redentorista Jaime Snoek, escreve um artigo na revista Concilium com o tema "Terceiro mundo, revolução e cristianismo". O texto começa mostrando a "fermentação revolucionária" na América Latina - AL, que a situação de opressão produziu uma "tomada de consciência" que causou "um clima pré-revolucionário e levou a AL a considerar-se envolvida naquilo que Toynbee chama de terceira onda revolucionária, a revolução do Terceiro Mundo" (SNOEK, 1966, p. 31). Na sua visão, a integração das "massas marginalizadas" não seria "possível sem a chamada revolução social" (SNOEK, 1966, p. 31). Além de A. Toynbee (A América e a Revolução Mundial, 1963), diversos outros autores são citados no artigo tratando o tema da revolução, como o presbiteriano Richard Shaull (O Cristianismo e a Revolução Social, 1953), o padre José Comblin (Nação e Nacionalismo, 1965), o leigo Cândido Mendes de Almeida (Nacionalismo e Desenvolvimento, 1963), o padre F. Houtart, com o artigo "Serviço social y transformación Social en América Latina", de 1962, como também diversos artigos do periódico chileno Mensaje, desde 1951. 
Snoek (1966, p. 32) entende por revolução "uma mudança deliberadamente produzida, rápida e profunda, que atinge todas as estruturas básicas (políticas, jurídicas, sociais e econômicas) e corresponde a uma ideologia e a uma planificação". Ela difere de um processo evolucionário, como também pensa Josaphat (2002), pois representa uma ruptura com a ordem, o status quo, e a criação de uma nova ordem.

Em sua leitura teológica da relação entre desenvolvimento e revolução, Jaime Snoek (1966) questiona que contribuição o cristianismo poderia dar. Buscando as mesmas bases já apresentadas por Frei Carlos Josaphat (2002) na "revolução" histórica da Encarnação do Verbo, na dinâmica constante de transformação da Criação e da Ressurreição, na renovação do Espírito, na utopia do Reino de Deus, considera que o cristão não pode "estranhar os processos revolucionários", muito menos se colocar indiferente e alheio. Afirma que só "aquele que tem fé e vive no âmago destas situações conflitivas percebe nelas algo que revela o plano de Deus" (SNOEK, 1966, p. 35). Apesar do cristão ter "horror" à violência, com a "preferência pela não-violência positiva", e de usá-la como último recurso, assim como Carlos Josaphat (2002), admite que "na fase actual da civilização, ainda não se pode excluir a priori a legitimidade de um recurso temporário à ilegalidade, à violência" (SNOEK, 1966, p. 38, grifo do autor), como reação à violência já praticada pelos poderosos. E corajosamente, no contexto da ditatura civil-militar e de sua perseguição, fala da "violência exercida discreta e silenciosamente pelo general Fome" (SNOEK, 1966, p. 38). Para o autor, todos devem ter "responsabilidades concretas": a Igreja, os leigos engajados no movimento revolucionário, a classe dirigente e os países desenvolvidos.

Essas bases e concepções que sustentam a revolução na perspectiva cristã terão grande impacto, especialmente na juventude católica, propiciando o desenvolvimento de uma nova teologia latino-americana: a Teologia da Libertação. Elas são formulações da modernidade, que foi, ao mesmo tempo, inaugurada pelo evento-força revolução e inaugurador da mesma. Modernidade e 
A revolução nas origens da esquerda católica brasileira e a Teologia da Libertação Wellington Teodoro da Silva • Paulo Agostinho N. Baptista

revolução se inauguraram mutuamente. Desse modo, na medida em que podemos falar que existe uma modernidade também falamos que a revolução permanece diluindo todos os sólidos no ar. A modernidade é o tempo da revolução permanente.

\section{Juventude, revolução e a Teologia da Libertação - TdL}

A Teologia da Libertação - TdL guarda uma relação muito importante com a juventude, que tem na ideia de revolução uma importante motivação, especialmente com a vitória do movimento liderado por Fidel Castro em Cuba, em 01 de janeiro de 1959. Conforme Luiz Alberto Gomez de Souza (1984, p. 9), a TdL teve na Juventude Universitária Católica - JUC um espaço importante para a sua germinação.

Até a década de 1950, os estudantes universitários católicos estavam reunidos na Juventude Brasileira Católica - JBC, que integrava a Ação Católica, e que incorporou a Associação Universitária Católica - AUC, em 1937. Era considerado um "apostolado organizado dos leigos que recebe um mandato da Hierarquia, portanto um apostolado oficial da Igreja. Assim, a missão da JUC - como da Ação Católica em geral - é a própria missão da Igreja: A evangelização..." (SOUZA, 1984, p. 123).

A história do envolvimento da juventude universitária com movimentos religiosos no Brasil começa com o redentorista Pe. Júlio Maria, no Rio de Janeiro, que criou a "União Católica Brasileira" - UCB, em 1908. Em 1929, sob a presença de Alceu de Amoroso Lima, mais conhecido como Tristão de Athayde, surge a AUC. Alceu assumiu o Centro Dom Vital, instituição criada por Jackson de Figueiredo, que morreu em 1928 e que era liderança católica reacionária aos processos de mudança.

A Ação Católica Brasileira - ACB começa no Rio de Janeiro, em 1932, com um curso para mulheres, e é formalizada pelo Cardeal Leme em novembro desse ano. Com grupos dispersos pelo país, 
A revolução nas origens da esquerda católica brasileira e a Teologia da Libertação Wellington Teodoro da Silva • Paulo Agostinho N. Baptista

somente em 1935 o Cardeal Leme cria os "Estatutos Gerais da Ação Católica", que se integrou à Ação Católica Geral - ACG, tendo na presidência Alceu de Amoroso Lima. Ainda marcada pela influência italiana, organiza grupos em Homens da Ação Católica (HAC), Liga Feminina da Ação Católica (LFAC), Juventude Brasileira Católica (JBC - masculina), Juventude Feminina Católica (JFC). Os estatutos preveem a JEC, a JUC e a JOC. A ACB, que ficará "geral" até o final dos anos de 1940, se especializa efetivamente em JAC, JEC, JIC, JOC e JUC (juventude agrária, estudantil, independente, operária e universitária) a partir de 1950 (CNBB, 1988, p. 37). A JUC será uma das grandes referências desse movimento e para a história da esquerda católica e da TdL.

Segundo Luiz Alberto Gómez de Souza, pode-se afirmar que há importante relação histórica entre TdL e JUC: "foi no Brasil e, mais precisamente na JUC, no início dos anos 60 que muitas das intuições do que constituiria mais tarde a teologia da libertação latino-americana, começaram a concretizar-se, num lento processo ligado a uma prática e, sobretudo, a uma prática política." (SOUZA, 1984, p. 9).

Gustavo Gutiérrez, teólogo peruano, um dos primeiros a produzir um livro da TdL, foi assistente nacional no seu país da União Nacional dos Estudantes Católicos (UNEC) desde o início de 1960. Segundo Gómez de Souza (1984), Gustavo, "quando redigia seu livro, hoje o clássico Teologia da Libertação, publicado em 1971, parou na metade e sentiu necessidade de vir ao Brasil para discutir certos detalhes e entrevistar alguns antigos militantes da JUC, sobretudo aqueles do período 1960-1963" (SOUZA, 1984, p. 9, grifo do autor). Também para Charles Antoine (1971, p. 65), a JUC foi um importante espaço de pesquisa "das novas relações entre a fé e a política".

A TdL começa a ser formulada na América Latina a partir dos anos de 1960, num contexto de opressão, de luta contra as formas de dependência e de colonização, fazendo emergir a voz de quem 
A revolução nas origens da esquerda católica brasileira e a Teologia da Libertação Wellington Teodoro da Silva • Paulo Agostinho N. Baptista

não a tinha ou não podia se manifestar. ${ }^{3}$ Num dos primeiros textos da TdL, entre 21 e 25 de julho de 1968 no Peru, Gustavo Gutiérrez (1968, p. 3-5) dizia que "a libertação significa [...] que sentido tem a obra terrestre [...], que relação há entre a construção do mundo e a salvação. [...] o homem é agente da história. [...]. A história é a história da emancipação humana.".

Mas antes de ser teologia acadêmica, ela se estrutura como práxis libertadora, nascida ecumenicamente em grupos e movimentos de libertação como o Movimento de Educação de Base MEC (1961), a Ação Católica Especializada (JUC, JEC e JOC), a União Cristã dos Estudantes do Brasil - UCEB, da Federação Universal dos Movimentos Estudantis Cristãos - FUMEC (protestante), as Comunidades Eclesiais de Base - CEBs, e diversos outros movimentos com trabalhadores, camponeses e estudantes.

O método da TdL - Ver-Julgar-Agir - foi inspirado no método desenvolvido pelo Padre e depois Cardeal Joseph Cardijn, fundador da Juventude Operária Católica - JOC, em 1923, na Bélgica. Em seu trabalho pastoral, com jovens operários, Cardijn pensou uma pedagogia de trabalho que virou também um método, conhecido inicialmente como método de revisão de vida. Além da JOC, a JUC e a JEC assumiram esse método.

Por isso a TdL, com a sensibilidade crítica de jovens, nasce da percepção e da visão da realidade, da indignação ética e espiritual diante do sofrimento dos empobrecidos, excluídos e oprimidos. Para Gutiérrez (1971, p. 74), “Falar de uma teologia da libertação é buscar resposta para a pergunta: que relação existe entre a salvação e o processo histórico de libertação do homem?". ${ }^{4}$ Em sua preocupação em ser uma "reflexão crítica sobre a práxis" (GUTIERREZ, 1971, p. 20), a TdL inovou em sua metodologia em relação à tradição teológica europeia. Ela articula os dois métodos, o método indutivo (Nouvelle Théologie), que se firma no Vaticano II, e a longa

3 A TdL deve ser pensada no plural, ainda mais hoje. Para Aquino Júnior (2016, p. 248), desde o início houve "uma diversidade e pluralidade enorme de teologias da libertação que poderia colocar em xeque qualquer pretensão de falar de TdL sem mais", no singular. Apesar de alguma unidade, há pressupostos teóricos, filosóficos, em cada teólogo da TdL, o que mostra grande diversidade. Conscientes disso, optamos no presente texto por tratar da TdL no singular.

4 "Hablar de una teologia da libertación es buscar respuesta al interrogante: qué relación hay entre salvación y el processo histórico de liberación del hombre?", em tradução nossa. 
A revolução nas origens da esquerda católica brasileira e a Teologia da Libertação Wellington Teodoro da Silva • Paulo Agostinho N. Baptista

tradição dedutiva (método dogmático e genético), mas na forma dialética, relacionando Evangelho e Vida, realidade histórica e fé, teoria e prática. E colhe o já tradicional, naquela época, método de revisão de vida, o Ver-Julgar-Agir, desenvolvendo e aprofundando seus passos.

Para Gutiérrez (1971, p. 131-132), a libertação é uma atitude profunda, que não se reduz ao processo econômico, social e político, mas à emancipação humana, que torna o ser humano livre de toda a servidão. Por isso, cita duas figuras importantes na formação política e praxística desse processo de cativeiro que exige uma atitude revolucionária: Che Guevara e Paulo Freire.

Diante de uma situação de opressão, de cativeiro, emerge na práxis de uma juventude inquieta a consciência da libertação. $E$ isso compromete jovens teólogos. Segundo Leonardo Boff, que começa a produzir seus primeiros textos teológicos efetivamente da TdL em 1974, ${ }^{5}$ "o cristão não é somente chamado a suportar heroicamente injustiças [...]. Há situações em que a consciência cristã se vê obrigada à denúncia global do sistema opressor e não vê outra saída senão pela revolução com a derrubada do regime ou pela morte suportada com galhardia e dignidade." (BOFF, 1976, p. 91).

Em sua metodologia, para que essa consciência libertadora possa ser refletida e assumida, a TdL utilizará de mediações: mediação sócio-analítica - MAS, para o ver criticamente a realidade; a mediação hermenêutica - MH, para o julgar a situação histórica à luz da Palavra de Deus, profética, anunciadora e denunciadora; e a medição prática - MP, para o agir transformador. E a mediação socio-analítica terá como "ferramenta" as ciências sociais para a apreensão crítica da realidade, sem deixar de utilizar a "ferramen-

\footnotetext{
5 Apesar do livro de grande destaque e importância - “Jesus Cristo Libertador”, de 1972 - ser considerado seu primeiro livro na perspectiva da TdL, a concepção cristológica de Leonardo Boff é ainda bastante marcada por sua visão filosófico-teológica alemã. Só a partir de 1974, quando começa a publicar artigos do que se tornaria, em 1976 (em português; 1975 em espanhol), o livro "Teologia do cativeiro e da libertação", é que se pode perceber a posição efetivamente libertadora de Leonardo. O livro "Jesus Cristo Libertador", a partir de 1986, em sua 16 edição, terá um novo capítulo 1 - "Jesus Cristo Libertador: o centro da fé na periferia do mundo" - que dará a perspectiva libertadora da TdL ao livro.
} 
A revolução nas origens da esquerda católica brasileira e a Teologia da Libertação Wellington Teodoro da Silva • Paulo Agostinho N. Baptista

ta" marxista, como afirmam Clodovis Boff (1984) e Michel Löwy (2000, p. 111-134). ${ }^{6}$

A gestação dessas ideias e práticas, que se constituirão na TdL, serão vividas e amadurecidas ao longo da experiência, da militância e da práxis dos grupos da JUC, JOC e JEC, a partir de 1960. Desde os anos de 1950 a JUC se organiza nacionalmente e em poucos anos atua para a criação da Juventude Estudantil Católica Internacional - JECI. Em 1956 essa entidade realizou seu primeiro encontro mundial no Rio de Janeiro.

Em 1960, a JUC chegou a ter em seus quadros cerca de $6 \%$ dos universitários, ou seja, um número próximo de 5.500 jovens para uma população universitária de 95.700 na época. E um momento muito importante da sua história foi o Congresso dos 10 anos, no Rio de Janeiro, também em 1960. Participaram do evento cerca de 500 alunos(as). A equipe de Belo Horizonte teve papel importante, pois desde 1959 propunha um debate sobre o "ideal histórico" da entidade, ideia lançada pelo assessor de Recife, Pe. Almery Bezerra, inspirado na visão de Jacques Maritain expressa no livro Humanismo Integral (MARITAIN, 1936).

O processo de organização dessa juventude universitária se desenvolveu numa dinâmica de autonomia, principalmente pela influência de seu assistente nacional, o dominicano Frei Romeu Dale (1949-1961). Vivia-se o contexto da revolução cubana, da guerra fria e, no Brasil, de mudanças: da era JK ao período de crises, da "vassourinha" de Jânio Quadros, da experiência parlamentar com Tancredo Neves, do governo de João Goulart e das manifestações de trabalhadores e estudantes pelas reformas de base. Na Igreja, havia a expectativa do Concílio Vaticano II (1962-1965), anunciado em 25 de janeiro de 1959, quase três meses depois de eleito o Papa João XXIII.

\footnotetext{
6 Sobre o método da TdL, cf. BOFF, Cl. (1978), BOFF, Cl.. (1993, p. 79-113), LIBANIO, (1987); BOFF, L.; BOFF, Cl, (1979). A TdL nasce "na" práxis e "da" práxis, e constrói sua "sintaxe", suas regras, consciente de que o teólogo tem autonomia e sofre dependência, está num duplo lugar: epistêmico e social. A construção teológica, no nível teórico, enquanto teoria teológica, se produz com a hermenêutica da fé (à luz de Deus, JULGAR), que se dá a partir de uma experiência espiritual (o encontro com Deus no pobre, no oprimido) numa práxis libertadora de toda opressão (nível prático), um primeiro VER. Este continua analiticamente, provoca a reflexão teológica (hermenêutica) e leva novamente "à" práxis. É, portanto, uma teologia dinâmica, que se dá na, da, para e pela práxis. A práxis irá cercá-la de toda forma, "de todos os lados".
} 
A revolução nas origens da esquerda católica brasileira e a Teologia da Libertação Wellington Teodoro da Silva • Paulo Agostinho N. Baptista

Já desde o final da década de 1950, a liderança da JUC desloca-se para outro espaço, do eixo São Paulo para Belo Horizonte. A construção de um "Ideal histórico", 7 com um "primeiro esboço apresentado pelo Pe. Almery Bezerra no IX Conselho Nacional da JUC, em Belo Horizonte, em julho de 1959" (BEOZZO, 1984, p. 85), ilumina as discussões, mas também trará as sementes da crise e do fim da JUC, pois projeta uma reflexão bem ampla, crítica, que inclui perspectivas religiosas, econômicas, sociais, políticas e culturais.

No Congresso dos 10 anos discutiu-se a temática "Algumas diretrizes de um ideal histórico cristão para o povo brasileiro" (LIMA, 1979, p. 84-97), apresentada pela equipe de Belo Horizonte. Envolvida com a realidade estudantil, a JUC lança em 1960 o estudante Herbert de Souza (Betinho) como pré-candidato à União Nacional dos Estudantes - UNE (TEIXEIRA, 2009). E cada vez mais ela assume o espaço político, especialmente no convívio propiciado pelo trabalho de educação, no Movimento de Educação de Base - MEB, e também no contato com trabalhadores e militantes sindicais de esquerda.

Esse Congresso defende que "a própria condição histórica que atravessamos parece acentuar a realidade de uma inserção no social, na encarnação total no temporal presente, o que poderia levar a pensar numa instância maior da ação sobre as estruturas" (BEOZZO, 1984, p. 89, grifo do autor). Objetivava-se articular de forma integrada a militância nos vários setores da vida social com a vivência religiosa. Isso acaba levando à crise com a hierarquia, especialmente quando se apoia, no nível dos valores, o socialismo, e em nível das estruturas, o engajamento temporal, o que expressa uma atitude de autonomia e "independência em relação à autoridade religiosa" (BEOZZO, 1984, p. 94), ainda mais diante de proibições como: "Não é lícito admitir-se que, ao formular a figura de uma Revolução Brasileira em assembleias ou círculos de estudos da JUC, se afirme doutrina de violência como válida e aceitável" (BEOZZO, 1984, p. 95).

7 Para Jacques Maritain (1946, p. 135), o ideal histórico é uma obra em construção, que responde pelo clima histórico, que mostra as linhas básicas de uma realidade futura. 
A revolução nas origens da esquerda católica brasileira e a Teologia da Libertação Wellington Teodoro da Silva • Paulo Agostinho N. Baptista

Todo esse processo acaba por conformar e consolidar o que já se chamava de "a esquerda católica", nascida especialmente no meio juvenil. Segundo Beozzo (1984), a realização das Semanas Sociais, começando na Universidade Católica do Rio de Janeiro em 1961, alimentará esse embrião "de um fenômeno novo, o de uma esquerda católica" (1984, p. 109). Alguns intelectuais são identificados por Beozzo (1984) nesse processo: "Hélio Jaguaribe, pertencente ao ISEB (Instituto Superior de Estudos Brasileiros), quer por Cândido Mendes de Almeida, também do ISEB e católico, quer pelo Pe. Henrique Vaz, SJ, professor da Faculdade Medianeira de Filosofia." (1984, p. 109). Ainda em julho de 1960, uma reunião com Henrique Vaz, Frei Cardonnel, Raul Landin, Antônio Octávio, Vinicius Caldeira Brant (que seria presidente da UNE entre 19621963), Carlos Diegues, Nelson Pompéia, Simon Schwartzman e César Guimarães havia discutido a ideia de se criar um grupo para a produção de uma revista. Tal ideia não vingaria, mas teria fruto depois com a criação da revista "Paz e Terra", em 1966.

Nesse contexto, a crise da JUC, especialmente a partir de 1961, propiciará o surgimento de outro movimento: a Ação Popular - AP. A realização da Semana Social na Universidade Católica do Rio de Janeiro, em 1961, produziu um importante documento: "Manifesto do Diretório Central dos Estudantes da Pontifícia Universidade Católica" (LANDIN et al., 1962, p. 89-98). Além de bases filosóficas e teológicas da ação do cristão na história e do papel do cristianismo, apresenta-se a missão do cristão e a "função do cristão universitário". Percebe-se sementes que germinarão na TdL, como nas afirmações: "A humanização do mundo que tem, para o cristão o duplo sentido de redenção e realização, desenvolve-se em momentos históricos" (LANDIN, 1962, p. 91); e "agir em ordem a colaborar para que as massas assumam a consciência de seus direitos e do imperativo histórico de sua ascensão" (LANDIN, 1962, p. 91); e ainda, "dar a esta consciência das massas o verdadeiro sentido da realidade nacional e do seu compromisso universal e humano." (LANDIN, 1962, p. 96); ou também: “O Cristo não pode ser episódico. O Cristo é um fim ao qual não apenas lutamos por 
A revolução nas origens da esquerda católica brasileira e a Teologia da Libertação Wellington Teodoro da Silva • Paulo Agostinho N. Baptista

chegar, mas cuja presença é uma certeza que se levanta a cada passo da nossa marcha ao encontro do homem." (LANDIN, 1962, p. 98).

No mês de julho de 1961, em Belo Horizonte, há a primeira reunião da AP, com o objetivo da criação do jornal, e em 1962, em fevereiro, na mesma cidade, o primeiro encontro da equipe, com a participação do "grupo do Rio", do pessoal da UNE (Aldo Arantes, presidente entre 1961-1962), do Pe. Henrique Vaz, do Pe. Henrique Lage, do Pe. Alípio Freitas, Pe. Almery Bezerra, jucistas de Recife como Andrea, totalizando "uma centena de pessoas, que durante uma semana discutiram e estabeleceram a fusão de todas essas forças com vistas a um movimento comum" (BEOZZO, 1984, p. 113). Um ano depois, em Salvador, há um encontro nacional, confirmando o nome do movimento e produzindo o documento-base, que na introdução afirma:

A Ação Popular é a expressão de uma geração que traduz em ação revolucionária as opções fundamentais que assumiu como resposta ao desafio de nossa realidade e como decorrência de uma análise realista do processo social brasileiro na hora histórica que nos é dado viver. (GOMÉZ DE SOUZA, 1984, p. 199).

O Golpe civil-militar, de 01 de abril de 1964, representará um abalo enorme para a esquerda católica, como prisões, exílios, torturas e desaparecimentos. Também coloca sério problema para a hierarquia católica. De um lado, havia o movimento que apoiava o golpe de estado, amparado na propaganda do perigo comunista; de outro, havia o grupo sensível à realidade dos trabalhadores, dos camponeses e estudantes, que defendia as reformas. A posição da CNBB - "Declaração da CNBB sobre a Situação Nacional" -elaborada em maio e divulgada em 02 de julho, mostra essa divisão: "graças a Deus, que atendeu às orações de milhões de brasileiros e nos livrou do perigo comunista, agradecemos aos Militares que, com grave risco de suas vidas, se levantaram em nome dos supremos interesses da Nação [...]. Por outro lado, não aceitamos [...] 
A revolução nas origens da esquerda católica brasileira e a Teologia da Libertação Wellington Teodoro da Silva • Paulo Agostinho N. Baptista

a acusação injuriosa [...] que Bispos, Sacerdotes e fiéis [...] a Ação Católica e o MEB sejam comunistas". (LIMA, 1979, p. 147-148). ${ }^{8}$

Nesse contexto, os conflitos com as lideranças da JUC acabaram levando ao fim do movimento em 08 de novembro de 1966, em Carta de Dom Vicente Scherer, Secretário dos Apostolados dos Leigos da CNBB. Deve-se destacar, no entanto, como já mencionado, a forte presença da JUC em quase $60 \%$ das cidades com cursos universitários, conforme a Tabela abaixo.

Tabela - A JUC em cursos superiores, Brasil (1950-1960)

\begin{tabular}{c|c|c|c}
\hline ANOS & $\begin{array}{c}\text { CIDADES COM CURSOS } \\
\text { UNIVERSITÁRIOS }\end{array}$ & CIDADES COM JUC & $\%$ \\
\hline 1950 & 45 & 13 & $28,9 \%$ \\
\hline 1952 & 49 & 18 & $36,7 \%$ \\
\hline 1955 & 61 & 28 & $45,9 \%$ \\
\hline 1957 & 71 & 35 & $49,3 \%$ \\
\hline 1958 & 75 & 37 & $49,3 \%$ \\
\hline 1960 & 88 & 52 & $59,1 \%$ \\
\hline
\end{tabular}

Fonte: SOUZA, 1984, p. 90

Esses números revelam que a presença universitária católica era bem significativa nas IES da época, num processo de crescimento entre os anos de 1950 e 1960, variando entre 28,9\% e quase $60 \%$ dessas instituições. Formaram-se quadros que ainda hoje têm participação ativa na igreja e na política. E além dos processos internos de crise, desencadeados na JUC pela discussão do seu ideal histórico, com a ampliação do conflito com a hierarquia, a ditatura acabou atingindo fortemente o movimento.

Para muitos dos seus militantes, assim como da AP e de outros movimentos, estudantis e sindicais, as opções eram: a clandestinidade e o enfrentamento, inclusive armado, à violência da ditatura; o exílio; ou o abandono de suas convicções. Muitos militantes enfrentaram o que consideraram coerência com seus valores e foram

8 De acordo com Beozzo (1984, p. 101), a Revista Eclesiástica Brasileira - REB publicou a Declaração da CNBB sobre a Situação Nacional em 02 de junho de 1964 (REB n. XXIV, p. 491-492) e o Jornal do Brasil também, em 03 de junho de 1964, na página 3 (LIMA, 1979, p. 147). 
presos, torturados e ficaram desaparecidos. Mesmo antes do golpe civil-militar já se assistia a desaparecimentos e crimes, como indica a dedicatória do livro "Cristianismo hoje" (1962), que faz referência "ao nosso companheiro Mike, seu revisor, tragicamente desaparecido em 8 de outubro de 1962". Um ano depois desse fato, ainda antes do golpe civil-militar de 1964, como um ensaio, outro grave crime acontecia com trabalhadores, em Ipatinga, então distrito de Coronel Fabriciano, em Minas Gerais, que ficou conhecido como "Massacre de Ipatinga". Seis mil trabalhadores em greve, aguardando o fim da reunião de negociação eram intimidados, e cerca de dezenove policiais militares, alguns num caminhão, abriram fogo aos trabalhadores, resultando em oito mortos, dentre eles uma criança que estava no colo de sua mãe, e 79 feridos. Na Foto 1, tirada minutos antes do início dos tiros, é possível ver o soldado Moacir Almeida no caminhão com a metralhadora em mãos.

\section{Foto 1 - Caminhão e a metralhadora do Massacre de Ipatinga}

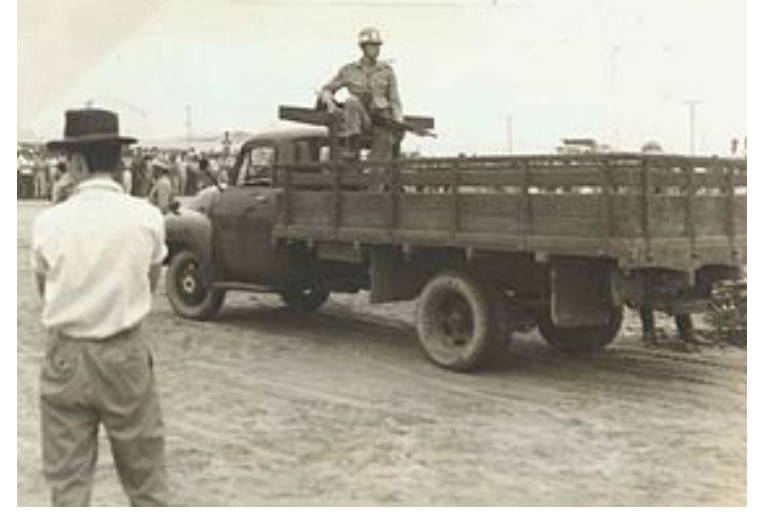

Foto de José Isabel do Nascimento - 1963.

Fonte: Fotos e Imagens sobre o Massacre de Ipatinga - Comissão da Verdade, 2019.

Assim como esses crimes do passado, continua hoje, de novas formas, a opressão através de mudanças nas leis trabalhistas e previdenciárias, na redução de recursos para a educação pública, na saúde, na legislação que não pune empresas como a Samarco e a Vale com seus crimes socioambientais de Mariana e Brumadinho, 
A revolução nas origens da esquerda católica brasileira e a Teologia da Libertação Wellington Teodoro da Silva • Paulo Agostinho N. Baptista

com centenas de mortos e danos incalculáveis às comunidades indígenas e ribeirinhas e ao meio ambiente e aos ecossistemas.

Por isso, é importante guardar a memória histórica e não esquecer que, além da juventude militante da esquerda católica, jovens teólogos foram importantes nesse processo de se pensar na transformação e na revolução social. A grande maioria dos principais teológicos da libertação, que estudaram fora do país (França, Bélgica, Alemanha, Estados Unidos), voltaram de suas pesquisas de doutorado ainda jovens, alguns com menos de trinta anos, outros não chegando a 35-40 anos de idade. Assim, pode-se citar José Comblin, Gustavo Gutiérrez, José Miguel Bonino, Rubem Alves, Juan Luis Segundo, José Porfírio Miranda, Hugo Assmann, Enrique Dussel, Jon Sobrino, Carlos Mesters, Frei Betto, Ignácio Ellacuría, Ronaldo Muñoz, Pabro Richard, Ruben Dri, Samuel Silva Gotay, Leonardo Boff, Clodovis Boff, João Batista Libanio, e muitos outros (DUSSEL, 1997, p. 52; LÖWY, 2000, p. 56).

As lutas pela libertação, a descolonização e a revolução continuam. Essa caminhada colhe a herança plantada com suor e sangue de muitos, inclusive mártires, que germina hoje em muitos movimentos e pastorais, como no Movimento dos Sem Terra MST, o Movimento dos Atingidos por Barragens, e muitos outros grupos e coletivos que lutam pela justiça socioambiental, pela transformação e pela revolução, ouvindo o "grito da terra e o grito dos pobres", ${ }^{9}$ e pela dignidade de todas e todos que são negados, que continuam oprimidos e excluídos, ainda mais nesses tempos tão sombrios.

O compromisso de jovens, mulheres e homens, trabalhadoras(es), desempregados e subempregados, no campo e nas cidades, de militantes de vários movimentos, de teólogos(as) da libertação e da esquerda cristã com a relação entre fé e política propiciou e continua a propiciar uma compreensão revolucionária da histórica, produzindo outra práxis e uma nova compreensão da

\footnotetext{
9 Referência ao livro de Leonardo Boff "Dignitas Terrae - Ecologia: grito da terra, grito dos pobres" (1995), feliz expressão da mudança de Boff, a partir de 1990/1992, incluindo na luta libertadora o "paradigma ecológico". Essa mudança afetou profundamente a teologia da libertação e as lideranças religiosas, como o Papa Francisco que, em 2015, lançou sua primeira encíclica sobre a ecologia: Laudato Sí (2015), com a participação de Leonardo Boff, e agora em 2019 promove, sobre fortes críticas internas e externas, o Sínodo da Amazônia.
} 
A revolução nas origens da esquerda católica brasileira e a Teologia da Libertação Wellington Teodoro da Silva • Paulo Agostinho N. Baptista

fé, marcados pelo compromisso proclamado por Jesus, em Lucas $(4,18)$, ao ler o livro do Profeta Isaías $(61,1)$ : “O Espírito do Senhor está sobre mim, porque me ungiu para anunciar a boa nova aos pobres; enviou-me para proclamar a libertação aos cativos, a restauração da vista aos cegos e para pôr em liberdade os oprimidos."

\section{Conclusão}

A história da esquerda católica já tem muitos registros importantes que ajudam a interpretar o presente, com vistas a sonhar com "outro horizonte possível", num contexto extremamente complexo pelo qual passa a América Latina e o Caribe, mas que também atinge o mundo todo. No entanto, a esperança sempre foi um referencial fundamental para esses cristãos do passado e do presente, alimentada pela fé revolucionária em Jesus e sua Ressurreição, que se nutre da práxis amorosa, começando com os menores e invisíveis, aqueles que não entram no planejamento econômico, mulheres e homens, crianças, jovens e adultos, empobrecidos, excluídos e oprimidos pela sua condição social e de classe, raça, expressão de sua sexualidade e gênero, posição política, cor da pele, e pelo espaço em que vivem.

Hoje a TdL amplia seus sujeitos e lugares teológicos, incluindo todas e todos, inclusive a Terra, cada vez mais explorada e, por isso, ameaçando as condições de vida e sobrevivência de todas as espécies.

Fazer memória é não esquecer dos que tombaram na luta pela libertação e pela construção do Reino de Deus, seus mártires, alguns nem eram cristãos, e que estão presentes não mais só na América Latina e Caribe, mas na África, na Ásia e em todos os lugares em que se luta pela libertação e pela descolonização. E já temos inúmeros mártires, alguns mais conhecidos e outros não: Carmilo, Torres, Che Guevara, Frei Tito, Arlen Siu, Margarida Maria Alves, Dorothy Stang, Chico Mendes, Santos Dias, Adelaide 
A revolução nas origens da esquerda católica brasileira e a Teologia da Libertação Wellington Teodoro da Silva • Paulo Agostinho N. Baptista

Molinari, Luisito Torres, Marielle Franco, o cacíque Jorge Guajajara, e muitas e muitos mais.

A luta pela mudança, pela libertação e pela revolução tem na juventude uma força importantíssima, pois as "juventudes" têm a energia para produzir o novo, revolucionar a história, como dizia Dom Hélder Câmara, profeta fundamental da Igreja e do Cristianismo da Libertação: "O segredo de ser jovem é ter uma causa a dedicar a vida". E esses jovens que formaram nos anos de 1960 a esquerda católica tinham essa causa e nos legaram referenciais profundos que não morrerão.

Alimenta a todos que lutam hoje pela libertação a palavra de outro mártir profeta, São Romero: "Ainda quando nos chamem de loucos, ainda quando nos chamem de subversivos, comunistas e todos os adjetivos que se dirigem a nós, sabemos que não fazemos nada mais do que anunciar o testemunho subversivo das bem-aventuranças, que proclamam bem-aventurados os pobres, os sedentos de justiça, os que sofrem." (Oscar Romero, em 11 maio de 1978).

\section{Referências}

ALMEIDA, Cândido Mendes de. Nacionalismo e Desenvolvimento. Rio de Janeiro: IBEAA, 1963.

ANTOINE, Charles. L'Eglise et le pouvoir au Brésil. Paris: Desclée, 1971.

AQUINO JÚNIOR, Francisco de. Questões fundamentais de Teologia da Libertação. Perspectiva Teológica, Belo Horizonte, v. 48, n. 2, p. 245-268, maio/ago. 2016.

ARENDT, Hannah. A condição humana. 10a ed. Rio de Janeiro: Forense Universitária, 2003.

BEOZZO, José Oscar. Cristãos na Universidade e na Política. Petrópolis: Vozes, 1984. 
BLOCH, March. Apologia da história ou o ofício do historiador. Rio de Janeiro: Jorge Zahar, 2001.

BOFF, Clodovis. O uso do "marxismo" em teologia. Comunicações do ISER, Rio de Janeiro, n. 8, p. 11-16, mar. 1984.

BOFF, Clodovis. Teologia e prática. Teologia do Político e suas mediações. Petrópolis: Vozes, 1978.

BOFF, Clodovis. Epistelomología y método de la teología de la liberación. In: ELLACURÍA, Ignácio; SOBRINO, Jon. Conceptos fundamentales de la teología de la liberación. Madrid: Trotta, 1990, p. 79-113.

BOFF, Leonardo. Dignitas terrae. Ecologia: grito da terra, grito dos pobres. São Paulo: Ática, 1995.

BOFF, Leonardo. Jesus Cristo Libertador: ensaio de cristologia crítica para o nosso tempo. Petrópolis: Vozes, 1972. [mudança na $16^{a}$. edição, de 1986].

BOFF, Leonardo. Teologia do cativeiro e da libertação. Petrópolis: Vozes, 1976. [1ª. Ediciones San Pablo, 1975].

BOFF, Leonardo; BOFF, Clodovis. Da libertação. 2. ed. O teológico das libertações sócio-históricas. Petrópolis: Vozes, 1980.

CARDONNEL, Frei Thomas. Deus não é mentiroso como certa paz social. In: SOUZA, Herbert José de; SOUZA, Luiz Alberto Gómez de. Cristianismo hoje. Rio de Janeiro: Universitária, 1962. p. 19-23.

COMBLIN, José. Nação e Nacionalismo. São Paulo: Duas Cidades, 1965.

CONFERÊNCIA NACIONAL DOS BISPOS DO BRASIL - CNBB. Declaração sobre a situação nacional. In: LIMA, Luiz Gonzaga de Souza. Evolução política dos católicos e da Igreja no Brasil: hipóteses para uma interpretação. Petrópolis: Vozes, 1979. 
CONFERÊNCIA NACIONAL DOS BISPOS DO BRASIL - CNBB.

Evangelização e Pastoral da Universidade. Estudos da CNBB 56. São Paulo: Paulinas, 1988.

FRANCISCO, Papa. Carta Encíclica Laudato Sí - sobre o cuidado da casa comum. São Paulo: Paulinas, 2015.

FURTADO, Celso. A pré-revolução brasileira. Rio de Janeiro: Fundo de Cultura, 1962.

GÓMEZ DE SOUZA, Luiz Alberto. A JUC: os estudantes católicos e a política. Petrópolis: Vozes, 1984.

GÓMEZ DE SOUZA, Luiz Alberto. Apresentação. In: SOUZA, Herbert José de; SOUZA, Luiz Alberto Gómez de. Cristianismo hoje. Rio de Janeiro: Universitária, 1962. p. 9-15.

GUTIÉRREZ, Gustavo. Hacia una Teologia de la Liberación. II Encuentro de Sacerdotes y Laicos en Chimbote, Perú, 21 y el 25 de julio, 1968. Teoria, crítica e história. Teología de la Liberación y contexto literario. Disponível em: http://www.ensayistas.org/ critica/liberacion/TL/documentos/gutierrez.htm. Acesso em: 12 jun. 2016.

GUTIERREZ, Gustavo. Teología de la liberación: perspectivas. Lima: Centro de Estudios y Publicaciones - CEP, 1971.

HOUTART, François. Serviço social y transformación Social en América Latina. Service social dans le Monde, Paris, n. 21, p. 122-129, 1962.

JOSAPHAT, Frei Carlos. Evangelho e revolução social. $3^{a}$ ed. São Paulo: Loyola, 2002.

LANDIN, Raul; ALENCAR, Marcos de; ARANTES, Aldo; DIEGUES, Carlos. Manifesto do Diretório Central dos Estudantes da Pontifícia Universidade Católica. In: SOUZA, Hebert José de; GOMÉZ DE SOUZA, Luiz Alberto. Cristianismo hoje. Rio de Janeiro: Editora Universitária, 1962. 
LIBANIO, João Batista. Teologia da libertação: roteiro didático para um estudo. São Paulo: Loyola, 1987.

LIMA, Luiz Gonzaga de Souza. Evolução política dos católicos e da Igreja no Brasil: hipóteses para uma interpretação. Petrópolis: Vozes, 1979.

LÖWY, Michel. A guerra dos deuses: religião e política na América Latina. Petrópolis: Vozes, 2000.

MAINWARING, Scott. A Igreja Católica e a Política no Brasil (1916-1985). São Paulo: Brasiliense, 1989.

MARITAIN, Jacques. Humanisme integral: problemes temporels et spirituels d'une nouvelle chretiente. Paris: Fernand Aubier, 1946.

MARSHALL, Berman. Tudo que sólido desmancha no ar - a aventura da modernidade. São Paulo: Cia das Letras, 1986. NASCIMENTO, José Izabel do. Fotos e Imagens sobre o Massacre de Ipatinga - Comissão da Verdade [s.d.]. Disponível em: http://www.comissaodaverdade.mg.gov.br/bitstream/handle/123456789/682/Fotos-Imagens\%20Sobre\%20Massacre $\% 20$ Ipatinga.pdf?sequence=1\&isAllowed=y. Acesso em: 30 jul. 2019.

OLIVEIRA, Pedro A. Ribeiro. "Libertação": ideia-força da "Esquerda Católica". In: GÓMEZ DE SOUZA, L. Alberto. (org.). Relativismo e transcendência. Rio de Janeiro: EDUSC, 2007. p. 31 - 45.

OLIVEIRA, Pedro A. Ribeiro. Estruturas de Igreja e conflitos religiosos. In: SANCHIS, Pierre (org.). Catolicismo: modernidade e tradição. São Paulo: Loyola, 1992. p. 41-66.

PRADO JUNIOR, Caio. A revolução brasileira. São Paulo: Ed. Brasiliense, 2004.

ROMMEN, Heinrich A. O Estado no pensamento católico - tratado de filosofia política. São Paulo: Paulinas, 1967.

SARTRE, Jean Paul. Furacão sobre Cuba. Rio de Janeiro: Editora do Autor, 1960. 
A revolução nas origens da esquerda católica brasileira e a Teologia da Libertação Wellington Teodoro da Silva • Paulo Agostinho N. Baptista

SHAULL, Richard. O Cristianismo e a Revolução Social. São Paulo: União Cristã de Estudantes do Brasil, 1953.

SNOEK, Jayme. Terceiro Mundo, Revolução e Cristianismo. Concilium, Petrópolis, v. 2, n. 5, p. 29-43, maio 1966.

TARSO, Paulo de. Os cristãos e a revolução social. Rio de Janeiro: Zahar Editores, 1963.

TEIXEIRA, Wagner da Silva. Os cristãos e as esquerdas nos anos 1960: uma historiografia da Ação Popular. In: MATA, Sérgio Ricardo da; MOLLO, Helena Miranda; VARELLA, Flávia Florentino (org.). Anais do $3^{\circ}$. Seminário Nacional de História da Historiografia: aprender com a história?. Ouro Preto: Edufop, 2009. Disponível em: http://www.seminariodehistoria.ufop.br/t/ wagner_da_silva_teixeira.pdf. Acesso em: 15 jun. 2015.

TOYNBEE, Arnold. A América e a Revolução Mundial. Rio de Janeiro: Zahar, 1963. 